Swarthmore College

Works

$10-1-1990$

\title{
Changes In Income Distribution In Poor Agricultural Nations: Malawi And Madagascar
}

Frederic L. Pryor

Swarthmore College, fpryor1@swarthmore.edu

Follow this and additional works at: https://works.swarthmore.edu/fac-economics

Part of the Economics Commons

Let us know how access to these works benefits you

\section{Recommended Citation}

Frederic L. Pryor. (1990). "Changes In Income Distribution In Poor Agricultural Nations: Malawi And Madagascar". Economic Development And Cultural Change. Volume 39, Issue 1. 23-45. DOI: 10.1086/ 451851

https://works.swarthmore.edu/fac-economics/129

This work is brought to you for free by Swarthmore College Libraries' Works. It has been accepted for inclusion in Economics Faculty Works by an authorized administrator of Works. For more information, please contact myworks@swarthmore.edu. 
Changes in Income Distribution in Poor Agricultural Nations: Malâ̂i and Madagascar Author(s): Frederic L. Pryor

Source: Economic Development and Cultural Change, Vol. 39, No. 1 (Oct., 1990), pp. 23-45

Published by: The University of Chicago Press

Stable URL: http://www.jstor.org/stable/1154102

Accessed: 28-04-2015 19:53 UTC

\section{REFERENCES}

Linked references are available on JSTOR for this article:

http://www.jstor.org/stable/1154102?seq=1\&cid=pdf-reference\#references_tab_contents

You may need to $\log$ in to JSTOR to access the linked references.

Your use of the JSTOR archive indicates your acceptance of the Terms \& Conditions of Use, available at http://www.jstor.org/page/info/about/policies/terms.jsp

JSTOR is a not-for-profit service that helps scholars, researchers, and students discover, use, and build upon a wide range of content in a trusted digital archive. We use information technology and tools to increase productivity and facilitate new forms of scholarship. For more information about JSTOR, please contact support@jstor.org. 


\title{
Changes in Income Distribution in Poor Agricultural Nations: Malaŵi and Madagascar*
}

\author{
Frederic L. Pryor \\ Swarthmore College
}

\section{Introduction}

Malaŵi (formerly Nyasaland) and Madagascar are poor, agricultural nations in southern Africa that have chosen very different strategies of development. Malawi carries a "capitalist"' label and has focused its governmental development efforts on the agricultural sector up to the early 1980s; Madagascar carries a "Marxist" label and, in the decade from 1975 to 1985 , has chosen to direct its major attention to the industrial sector. In some respects, the economic performance of the two nations has been very different: for instance, between 1960 and 1986, Malawi had an average annual increase of per capita GDP of about $1.6 \%$, while Madagascar had an average annual decrease of about $1.1 \% .^{1}$ In other respects, performance was relatively similar. For instance, both countries experienced widening differentials of income and increasing poverty, but especially Malawii.

In poor agricultural nations, an increasing inequality in the distribution of income for the nation as a whole can come about for three reasons. ${ }^{2}$

1. The income inequalities within the urban or rural sectors widen. As shown below, the greater income differentials in the rural sectors of the two countries were the most important factors underlying the overall increasing inequalities of income.

2. The relative number of families increases in the urban sector (as long as the urban sector accounts for less than half of the population), where average incomes are higher. Although such a population movement occurred to a limited extent in both countries, it did not have an important impact on the overall distribution of income.

3. The disparity in average incomes of families in the urban and rural sectors widens. In both Malawi and Madagascar, however, this 
disparity narrowed, primarily because real family incomes in the urban sector fell considerably.

In this article I examine the available income distribution data, then turn to the policy variables underlying the intrasectoral and intersectoral income differences, and finally focus on some physical indicators of poverty in order to explore what happened to incomes at one end of the income distribution.

\section{Basic Trends in the Income Distribution}

The tentative nature of data presented below must always be kept in mind; the estimates are pieced together from a variety of surveys of family income in different sectors at different times, adjusted whenever possible to make them comparable. For Madagascar, special problems arise because the income data are not consistent with the production data. The estimates designated " $\mathrm{A}$ " combine the various income surveys without taking such consistency problems into account, and, as a result, they probably understate actual income inequality. The estimates labeled " $B$ " are made by adjusting the rural and urban income data so that the totals roughly equal the relevant national income aggregates; they probably overstate income inequality. The exact methods of estimation are published at length elsewhere $;^{3}$ the key estimates are presented in tables 1 and 2 .

The data in table 1 show considerable income inequality in the two nations and a marked increase in income inequality over time, especially in Malawi. The data in table 2 present overall measures of average family incomes and family income inequalities for particular population groups. Such data also permit us to separate the impact of intergroup and intragroup differences by setting all incomes in a particular group equal to the group average; such a procedure only works for those inequality coefficients that are decomposable, that is, the log variance and the Theil statistics.

\section{Structural Features of Income Inequality}

Several features of these estimates immediately draw our attention. First, in both countries the single most important factor underlying the overall inequalities of income was the difference in average income between urban and rural populations. This can be shown by comparing the income inequality coefficients for the entire economy without adjustments to the hypothetical situation where all incomes in a particular population group are equal to the mean. In three of the four cases the inequality coefficients in the latter case accounted for roughly one-half or more of total income inequalities.

Second, in both countries the inequalities in the rural sector were considerable, particularly in the later year. It is sometimes claimed that in the rural sector of developing countries the distribution of income is 


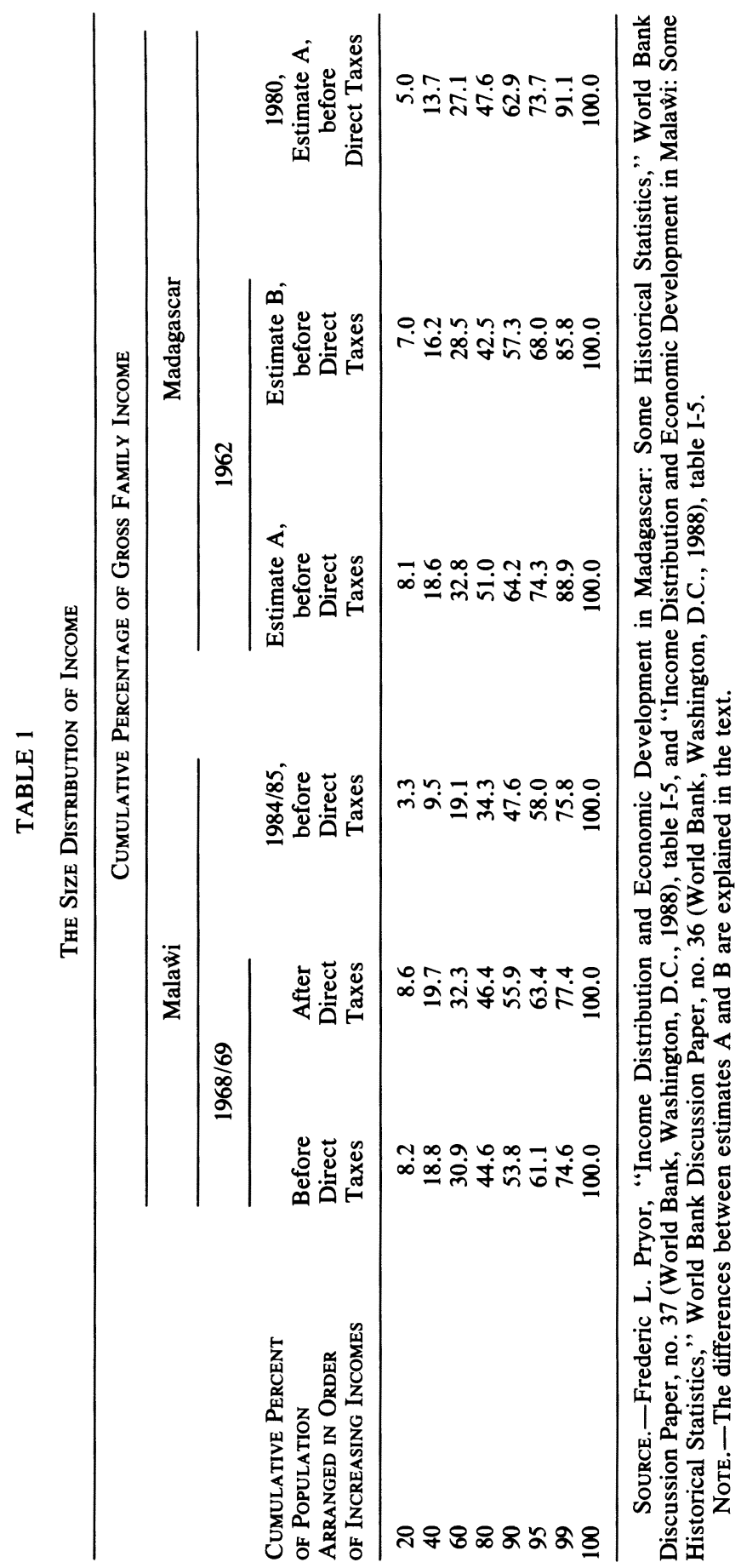


TABLE 2

Income Inequality Statistics for Malâ̂i and Madagascar

\begin{tabular}{|c|c|c|c|c|c|}
\hline \multirow[b]{2}{*}{ GROUPS OF FAMILIES } & \multirow[b]{2}{*}{$\begin{array}{c}\text { NUMBER } \\
(1,000)\end{array}$} & \multirow{2}{*}{$\begin{array}{l}\text { AvERAGE } \\
\text { TOTAL } \\
\text { INCOME* }\end{array}$} & \multicolumn{3}{|c|}{$\begin{array}{l}\text { INEQUALITY } \\
\text { COEFFICIENTS }\end{array}$} \\
\hline & & & Gini & Theil & $\begin{array}{l}\text { Log } \\
\text { variance }\end{array}$ \\
\hline \multicolumn{6}{|l|}{ Malaŵi: } \\
\hline \multicolumn{6}{|l|}{ 1968/69: } \\
\hline Smallholder families & 885.0 & 86.42 & .203 & .113 & .118 \\
\hline Families on estates & 28.0 & 140.31 & .187 & .093 & .110 \\
\hline Families in small towns & 11.0 & 606.93 & .466 & .417 & .651 \\
\hline Families in four major towns & 42.6 & 907.65 & .660 & .884 & 1.494 \\
\hline Total/average & 966.5 & 130.03 & 448 & .796 & .317 \\
\hline $\begin{array}{l}\text { Assuming all incomes in a } \\
\text { group equal to mean of group }\end{array}$ & 966.5 & 130.03 & .317 & .432 & .274 \\
\hline 1984/85: & & & & & \\
\hline Smallholder families & $1,252.0$ & 358.2 & .453 & .348 & .607 \\
\hline Families on estates & 89.2 & 425.1 & n.a. & n.a. & n.a. \\
\hline Families in small towns & 34.2 & $2,157.1$ & n.a. & n.a. & n.a. \\
\hline Families in four major towns & 98.5 & $3,235.4$ & .621 & .776 & 1.065 \\
\hline Total/average & $1,473.9$ & 596.2 & .599 & .944 & .860 \\
\hline $\begin{array}{l}\text { Assuming all incomes in a } \\
\text { group equal to mean of group }\end{array}$ & $1,473.9$ & 596.2 & .365 & 447 & .361 \\
\hline \multirow{2}{*}{\multicolumn{6}{|c|}{$\begin{array}{l}\text { Madagascar (estimate A): } \\
1962 .\end{array}$}} \\
\hline & & & & & \\
\hline Rural & $1,076.2$ & 60.9 & .290 & 194 & .220 \\
\hline Secondary urban centers & 36.6 & 153.6 & n.a. & n.a. & n.a. \\
\hline Largest six towns & 98.9 & 199.3 & .500 & .466 & .806 \\
\hline Total/average & $1,211.7$ & 75.0 & .391 & .371 & .352 \\
\hline $\begin{array}{l}\text { Assuming all incomes in a } \\
\text { group equal to mean of group } \\
\text { 1980: }\end{array}$ & $1,211.7$ & 75.0 & .168 & .106 & .125 \\
\hline Rural sector & $1,542.9$ & 192.9 & .435 & .329 & .517 \\
\hline Secondary urban centers & 140.5 & 356.2 & .487 & 399 & .747 \\
\hline Largest seven towns & 227.3 & 462.7 & n.a. & n.a. & n.a. \\
\hline Total/average & $1,910.8$ & 237.0 & .489 & .426 & .628 \\
\hline $\begin{array}{l}\text { Assuming all incomes in a } \\
\text { group equal to mean of group }\end{array}$ & $1,910.8$ & 237.0 & .154 & .065 & .096 \\
\hline
\end{tabular}

Note.-All of the coefficients become larger when inequality increases. The Gini coefficient lies between 0.0 and 1.0; the others are unbounded. As noted in the discussion, the estimates for the two countries are not quite comparable. For each country, however, the results are roughly comparable over time. Sources are the same as in table 1. n.a. = not available.

* Income in Malawii Kwacha for Malawii and Malagasy Francs for Madagascar.

relatively equal since the average incomes are so close to the starvation limit. Such an argument-often attributed to Simon Kuznets but found in earlier literature as well-does not take into account either the fact that there are a number of relatively wealthy peasants, so that the distribution has a long tail, or that these data are based on household income and would be more equal if income per person were the basis of the calculation. 
In addition, because of the manner in which the Madagascar data are estimated, the overall inequality coefficients for the two countries cannot be directly compared without further adjustments. ${ }^{4}$ When such adjustments are made (a weighted average of estimates $A$ and B), it appears that income inequalities in the rural sector of Madagascar were greater, especially in the earlier year. This occurred because land was less equally distributed among smallholders in Madagascar than in Malawii, a feature arising from differences in the land tenure arrangements: in Malawi tenancy was very infrequent and a family could hold only as much land as it farmed; in Madagascar, the land was more privatized. $^{5}$

Finally, Madagascar had a greater overall equality of income, due primarily to its narrower urban-rural income differentials. As noted, some incomparabilities exist between the data of the two countries, but the differences in average incomes in the urban and rural sectors were too great to be explained by differences in statistical definitions in the two nations.

\section{Changes over Time}

Aside from the increasing inequality of overall income, some other important temporal changes should be noted. The changes in income distribution, for instance, were particularly important in the rural sector, which also had the lowest average income; in the urban sector, income differentials seemed to remain roughly constant. In Madagascar, however, the estimation procedure may have understated any adverse changes in the urban sector; and, moreover, in the mid-1980s the income inequalities in the cities undoubtedly increased as unemployment rose and the rice subsidy was removed. Also, the influences of migration from the low income rural sector to the higher income urban sector were not important in either country. More specifically, simulations of the impact of population shift using the data in table 2 made little difference in the calculated inequality coefficients. ${ }^{6}$

\section{Intrasectoral Income Differences}

\section{Urban Sector}

In the urban sector I found little evidence that the Malawi government intervened in a conscious manner to change the distribution of wage income. The government's basic needs strategy focused more on the raising of income levels than on distributional issues per se. The wage control policies focused primary attention on the average wages in particular sectors, rather than on the structure of wages per se.

In Madagascar the situation was quite different and the most important measures deserve a brief review. In the period from 1977 to 1979 the government took three steps to influence the urban income distribution: first, it raised the minimum wages in the lowest wage 
categories at a faster rate than the minimum wage in higher categories; second, it revised the civil service pay scale to favor the lowest paid workers (and to freeze the pay of the higher civil servants); and third, it also began to subsidize sales to the urban sector of such basic products as rice, the main staple and the largest single purchase in the budgets of the poor. This acted in a progressive manner on the urban income distribution but had a regressive effect for the income distribution of the nation as a whole since such subsidies were essentially financed by the rural sector which received a price lower than a free market price for its crops (especially those farmers who produced crops for exports). The subsidy on food consumption of the urban population was eliminated in the mid-1980s as part of the liberalization program, a policy step particularly painful to the government.

The Malagasy government also implemented a number of other policies to narrow the income distribution in urban areas, but these often achieved results opposite to what was intended. For instance, in the 1980s the government set low prices for edible oils and condensed milk (two important commodities in the household budgets of the poor), but this led to a decline of domestic production and their availability to the poor.

\section{Rural Sector}

Increases in income inequality within the rural sector-particularly among smallholders-were the critical factor underlying the overall increase in income inequality in both nations. Before turning to the impact of various governmental policies, it is useful to consider for a moment the impact of diminishing returns to labor on the land, a factor also leading to greater rural income inequalities. Although both countries experienced a land shortage, they responded in different manners.

In Malawi the average size of a smallholder farm declined markedly from the 1960s through the mid-1980s; there was very little unused arable land to be found, especially in the most populous southern region, so the rural economy was operating on the intensive margin. Since techniques of land intensification were not yet introduced on a large scale, it seems likely that the same percentage population increase in the three regions (north, central, and south) would drive average agricultural incomes further down in the southern region where diminishing returns were more severe than in the other regions; and, indeed, this appears to have happened. ${ }^{7}$ In Madagascar the average smallholder's farm increased in size, but both land and labor productivity were falling, that is, the rural economy was operating on the extensive margin and was bringing into production land of increasingly bad quality. This mechanism slowed to some degree the widening of regional income inequalities in the rural sector.

Government policies played, I believe, a more important role than 
diminishing returns in influencing the distribution of rural income, and these measures need careful consideration for each country. The argument can only be made in a qualitative fashion since the available data do not permit an exact determination of the impact of the various policies.

Malâwi. Hastings Kamuzu Banda led his country to independence in 1964 and has remained in power ever since. His government followed an agricultural policy toward the smallholders that might be labeled (after a similarly oriented policy of the last Russian tsar) a "wager on the strong," focusing most of the public resources placed in agriculture on the richest farmers.

Before outlining the way in which such a strategy was implemented, I must emphasize that a wager on the strong is a defensible development strategy if three conditions are met: if resources channeled to the strong are more productive than if expended on the rest of the agricultural sector; if there is some trickle-down of the benefits from the wealthier part of the agricultural sector to the poorer; and if the poorer part of the agricultural sector is not disadvantaged by other government policies, by natural conditions, or by its interaction with the wealthier part of the agricultural sector. Although it lies beyond the scope of this article to argue these matters in detail, none of the three conditions were met in Malawii. ${ }^{8}$ The particular agricultural policies of the Malawi government have given rise to considerable criticism.

The Malawi government carried out its wager on the strong in a variety of ways, of which the most important were:

a) In its development budget (roughly, the capital budget), the government invested from one-half to two-thirds of all resources in four large-scale integrated development projects. Before the projects started, three of the four development areas had average net farm incomes roughly twice as high as the national average; the fourth had average farm incomes slightly below the national average. Furthermore, within each of the four development areas, the number of families actually adopting the "technology and credit" package was less than one-third of the total number of families, so that the governmental funds focused on a relatively small percentage of the total population.

b) The technology and credit package, which the government offered smallholders, required them to use certain agricultural techniques in return for credit to purchase fertilizers, seeds, and other inputs. Such a package, however, involved the purchasing of large quantities of fertilizer, and such input amounts were suitable only for relatively large farms. The seeds were also for a hybrid maize for export, which was planted only by the richest smallholders. This is because such hybrid maize did not store well and also did not correspond to local tastes. The poorer smallholders followed a "safety first" 
strategy by first planting enough of the local maize to feed their families; only those with considerable extra land would plant the hybrid maize to the extent that they were able to take advantage of the technology and credit package. It should not be surprising, therefore, that most credit went to the wealthier smallholders. In the most recent long-term plan, this situation was noted and policies were planned for the late 1980s which would lead to a much wider distribution of credit and a change in the package so as to be more suitable for the smallholders with relatively small farm areas. ${ }^{9}$

c) The poorer farmers were forced to sell all of their export crops as well as most of their domestic crops destined for the urban areas to the Agricultural Development and Marketing Corporation (ADMARC), a monopsonistic purchasing parastatal. Over the decade of the 1970s ADMARC paid an increasingly lower percentage of the world market price. A particular set of richer farmers-designated "master farmers"- - were permitted to sell their export crops at world market prices and receive considerably higher prices. They also received a priority in the supply of farm inputs, whenever these were scarce because of foreign exchange shortages, and special credits.

d) Although Malawi had a relatively impressive network of extension workers, this service did not reach certain subsectors of the smallholding sector, for example, female-headed households, which made up about one-third of all rural households in the most populous region and which were often the poorest households. Agricultural research was also not oriented toward the problems faced by the poorest smallholders.

e) In its educational policies, the Malawi government placed little emphasis on increasing the primary school enrollment. This disadvantaged the poor families in the rural sector and contributed to income inequality.

Malawi was one of the few African countries to pursue in a conscious fashion a development strategy favoring the agricultural sector. The government, however, provided the greatest help to two subsectors: the richest smallholders and the public and private estates. The estates were aided by generous credit from state banks, a method used by the government to circumvent the bureaucracy in the Ministry of Agriculture. The gamble on estate production paid off since such production was the leading sector underlying Malawi's economic growth during the 1970s.

Although many have criticized Malawii's emphasis on estates, such policies did not have a direct effect on the distribution of income within the smallholder sector; the indirect effects were minor. ${ }^{10}$ It was the wager on the strong that led to a widening of rural income differentials. Malawi thus serves as an important counterexample to the oft- 
made but careless generalization that a development strategy based on agriculture per se leads to a more equal distribution of income.

Madagascar. In Madagascar the situation was rather different. After independence in 1960 the government of Philibert Tsiranana placed a considerable share of its development budget in the rural sector. It followed, however, a wager on the strong strategy, with emphasis on certain integrated development projects and with government aid and credit directed primarily at the richest smallholders and the estates.

The government of Gabriel Ramanantsoa (1972-75) attempted both to increase the share of government investment in the rural areas and to reverse the emphasis on aiding the richest farmers. Some observers have argued that during this period there was a considerable change in the village leadership and the distribution of such governmental aid, with more aid going to farms of smaller size; these matters, however, cannot be easily confirmed.

The socialist government of Didier Ratsiraka (1975 to the present) followed a much different development strategy, decreasing investment in the rural areas and increasing investment in industry. In 197879 it inaugurated a program of "invest to the hilt" (a Malagasy version of the Chinese Great Leap Forward), which had catastrophic results: a quintupling of the foreign debt, a dramatic decline in per capita GDP, and a chronic balance-of-payments crisis lasting for a decade. During the Ratsiraka period up to the mid-1980s, the following policies influenced the distribution of income in the smallholder sector.

a) After 1975 agricultural credit was channeled primarily to the richer smallholders and estates, especially since several programs offering credit to smaller farms were cut back or dropped.

b) During its first decade the Ratsiraka government diverted funds for maintenance of the roads to other purposes. Given the minor importance of railroads and other means of transportation of crops, this meant that the major impact of the breakdown of transportation fell on areas far removed from the cities; and those areas also had the lowest per capita incomes.

c) The Ratsiraka government turned the internal terms of trade against the rural sector so that real agricultural prices were lower than before. ${ }^{11}$ This meant that those farmers who relied primarily on their sales to official governmental purchasing agencies received less for their products; they were, in large part, smallholders with relatively little to sell, that is, the lower income smallholders.

d) The Ramanantsoa government began nationalizing the crop purchasing companies, and the process was completed by the Ratsiraka government. As an inadvertent result, there was a breakdown of markets. This can be seen by examining the coefficient of variation of 
market prices for various agricultural products in the 17 subprefectures: the statistic shows a tripling of the weighted coefficient of variations between the early and the mid-1970s. Important parallel markets for foodstuffs developed in the cities, and those most able to take advantage of the high prices (often more than double the official prices) were usually the richest farmers, who had the resources to bribe or purchase trucking services.

e) The foreign exchange scarcity induced by the overvalued exchange rate made it difficult for many to obtain the necessary agricultural inputs such as insecticides and fertilizers, not to mention consumer goods. This development also benefited the richest farmers since they had the working capital for payments to obtain the scarce inputs or to pay parallel market prices for consumer goods.

$f$ ) Although the various Malagasy governments made valient efforts to achieve $100 \%$ enrollment rates in the primary schools, illiteracy did not fall the fastest in the poorest provinces. Further, during the decade after the 1970s, graduates of various schools had considerable difficulties in finding jobs commensurate with their education. Thus, education did not appear to narrow income differences, at least during the period under investigation.

\section{Changes in the Ratio of Urban and Rural Incomes}

A very important feature of the income structure in both countries was the very great difference between average incomes in the urban and rural sectors, and the narrowing of such differentials over time. This has acted to lower overall income inequalities, that is, to counteract the impact of the widening income differentials in the rural areas.

Although the differences beween the two countries appear considerable, they are due in part to the nature of the data. If we adjust the Malagasy income data to make them more consistent with production data (i.e., estimate B), the urban-rural differences become twice as great (as estimate A). Furthermore, the Malawi data include expatriates in the urban sector; the Madagascar data exclude them. If the data were made comparable in this manner, the Madagascar ratio of average urban to rural incomes would undoubtedly be still higher.

The differences between urban and rural incomes between the two countries are not just statistical artifacts but also reflect some real contrasts. During colonial times the French farmers in Madagascar were much more widespread through the countryside than the English were in the Nyasaland colony. In order to aid these colonists, the French also invested considerably in rural infrastructure, which, to a certain extent, aided the Malagasy smallholders as well. In Malawii, governmental investment in the rural sector was relatively small until after the Second World War.

From the data presented in table 2 this urban/rural income differ- 
ence can be studied from various aspects. Of greatest importance is that both countries reveal a narrowing of the urban/rural income gap because real urban incomes fell between the 1960s and the 1980s.

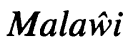

In Malawi between 1968/69 and 1984/85, average smallholder family income increased roughly $6 \%$, while such income in the major towns declined about $25 \%$. Among smallholders it is noteworthy that real family income from wages and salaries (representing off-farm employment) declined about $42 \%$, largely because the part-time jobs in the urban areas previously held by smallholders were now being taken by rural dwellers moving permanently to the informal sector in the towns.

Underlying this fall in urban income was a decrease in the real wage. From 1968 through 1985 average real wages in the modern sector fell at an average annual rate of about $3.8 \%$ a year. Several mechanisms appear to account for this dramatic decline.

Rise of profits at the expense of wages. Over the period 1968-85, the share of profits in the national income increased considerably, while the share of wages fell. In the decade before independence, the share of property income from the modern sector in the total national income fluctuated between $5 \%$ and $10 \%$; after independence it rose to a high of $23 \%$ in 1977 , before falling to $15 \%$ in 1979 , the last year for which such data are available. A Stolper-Samuelson-Rybczynski mechanism appears to have been in operation, that is, capital- (and land-) intensive production increased at a faster rate than more laborintensive production, which raised the relative share of property income in the total national income. More specifically, agricultural exports rose faster than the GDP; the Central Bank maintained the exchange rate at roughly the equilibrium level; the relative prices of traded goods (crops) rose in comparison to nontraded goods and services; incomes in the sectors selling these export goods increased; and real wages in the sector producing nontraded goods (which includes many urban workers) fell. ${ }^{12}$ The fall in the wage share led to a fall in urban incomes since the increase in total income in the economy was not sufficiently great to offset such changes.

Composition of the urban labor force. Part of the fall in real wages for the economy as a whole can also be attributed to a shift in the composition of the labor force so that the lower paid agricultural workers (estate workers) constituted a larger share of employment in the modern sector. In the urban sector alone, however, real wages have experienced an average annual fall of $3.2 \%$; moreover, there was a shift toward jobs paying lower than average wages. ${ }^{13}$ For instance, between 1969 and 1976, three-quarters of the newly created private-sector jobs were for unskilled jobs at wage levels below the average wage; such a composition effect lowers average wages over time, even if real wages 
for every specific job remained the same. Scattered evidence also suggests that as Malawians began to fill high income jobs previously held by European expatriates, the salaries of these jobs were also reduced. Although adequate wage data to analyze the question in detail are not available, I suspect that real wages for most specific jobs probably declined over the period, although at a relatively slow rate.

Other factors. Unemployment per se was not responsible for any fall in average real wages, since the rate of joblessness appears low. ${ }^{14}$ Malawii had a considerable shortage of skilled workers, and, indeed, there was a relative rise of wages and salaries of those with more education in the years 1966-77. The joblessness that occurred was primarily among the unskilled, and this undoubtedly acted to pull down real wages at the low end of the wage scale. Aggressive actions by the labor unions to prevent this fall in real wages was also discouraged by the government.

\section{Madagascar}

In Madagascar between 1962 and 1980, average family incomes in the rural sector remained roughly the same while such incomes (excluding expatriates) in the major towns declined about $27 \% .{ }^{15}$ Real wages in the modern sector fell throughout the entire independence period. From 1960 and 1970 real average annual wages in the private sector declined slowly-about $0.8 \%$ a year; and from 1966 through 1984, average annual wages of industrial workers fell faster-at about $2.3 \%$ a year. Several contrasts can be drawn with Malawii.

Rise of profits at the expense of wages. Although profit data are not available, it does not appear that this factor was very important. After 1975 considerable nationalization took place and the parastatal sector was subsidized, rather than serving as a source of profits. Furthermore, the Stolper-Samuelson-Rybczynski mechanism was not operative because foreign trade increased more slowly than the GDP and the relative prices of tradables did not greatly change in comparison to nontradables.

Composition of the urban labor force. Employment in the modern sector increased during the period from 1960 through 1984 at roughly $2.3 \%$ per year, which was considerably lower than the $6.1 \%$ annual rise in population in the urban areas. Since the modern sector in the countryside was not an important source of employment growth, the urban informal sector absorbed the new labor. Although the income of those in the informal sector is not included as wages, it had a depressing impact on the lowest urban wages. Within the formal urban sector, the fastest growing segment was the government sector, and in recent years the government raised wages at a much lower rate than inflation in order to reduce the government deficit.

Other factors. Unemployment was much higher in Madagascar 
than in Malawi. For instance, in 1980 the unemployed in the urban areas registered as seeking work amounted to over $8 \%$ of the labor force outside of agriculture; and from 1970 to the mid-1980s, the number of those registered as unemployed tripled. Actual unemployment was, of course, much higher than was registered unemployment. Antananarivo, the largest city, for instance, had an unemployment rate of more than $30 \%$ in the early 1980 s. ${ }^{16}$ Such unemployment exercised a downward pressure on wages.

\section{A Note on Poverty}

To what extent did the growth-or decline-of per capita income influence the income of the poorest segment of the population? One method of studying the problem is to take as the "poverty line" the income of families in the fortieth percentile in an early year and then to determine the percentage of families with incomes (adjusted for changes in prices) below this poverty line in a later year. Using this procedure we find that the percentage of those in poverty increased in both countries, especially Malawii. ${ }^{17}$ Contrary to expectations based on general considerations of the nature of economic growth, poverty increased more in the country with the highest growth of per capita income.

This rather startling conclusion does not, however, correspond with more casual evidence of the very poorest from both countries. For instance, there is less visual evidence of human misery in Malawi than in Madagascar. ${ }^{18}$ Also, unless the particular statistic used to calculate the overall inequality of income places particularly heavy weight on the lowest income levels, it is by no means certain that comparisons of the entire income distributions of the two countries would yield the same results as comparisons of the truly destitute.

Given the uncertain nature of income data at lower levels in any country, comparisons of poverty can be carried out best by examining a series of physical indicators of well-being that are particularly sensitive to real incomes of the poorest segment of the population. Such data suggest that the extent of poverty does not appear very different in the two countries; in other words, the inequality statistics presented in the discussion above do not capture an important aspect of the income distribution. The physical data also reveal different trends over time.

\section{Infant Mortality}

Although at independence Malawi and Madagascar had quite different rates of infant mortality, these rates appear to have converged by the mid-1980s.

In Malawi infant mortality declined from about 204 per thousand in 1967 , to 176 per thousand in 1977 , to roughly 160 per thousand in 1982. ${ }^{19}$ This does not necessarily indicate a fall in poverty as measured 
by income since infant mortality has decreased in many African nations where poverty has not decreased; it does, however, show an increase in physical well-being.

For Madagascar information about infant mortality rates is much more uncertain. ${ }^{20}$ For 1975 , estimates range from 68 per thousand (the official census datum) to 160 per thousand (a rather uncertain calculation based on use of fertility rates and age distribution data). In later years similar data uncertainties occur and, for 1985, my own estimate is that infant mortality was roughly 150 per thousand, although this may be on the high side. There is considerable evidence that infant mortality rates increased from the late 1970s through the mid-1980s, only part of which can be attributed to improvements in the system of collecting mortality information.

\section{Birth Weight}

Aggregative information on the birth weight of infants is often used as a measure of the nutritional status of the women bearing the children. ${ }^{21}$ In Madagascar, a nationwide sample survey in 1984 revealed that $14.4 \%$ of the infants had a birth weight of less than 2,500 grams; smaller scale studies record considerably higher percentages. In Malawi only partial studies are available; one survey of all babies born in Malaŵi hospitals and health centers in July 1964 (admittedly only a fraction of total newborn babies) showed that $16.5 \%$ had birth weights lower than 2,500 grams. The difference in these percentages between the two countries appears significant; however, the quality of the data are poor, and not too much emphasis should be placed on such results.

\section{Measurements of Weight and Height of Children}

Anthropometric data of children revealing undernourishment are increasingly used as measurements of absolute poverty. ${ }^{22}$ The undernutrition data suggest few important differences in the two countries.

For Malawi data are available from an impressive national survey of children of smallholders, which was carried out in conjunction with the 1980/81 National Sample Survey of Agriculture. For Madagascar a considerable number of smaller scale studies have been carried out on the topic, and for table 3 I have used data from three recent studies, which, unfortunately, covered relatively prosperous areas. It is likely, therefore, that a nationwide study would show greater undernutrition. Also included in table 3 is similar information for other countries so that an international perspective can be gained.

A weight/height ratio smaller than $90 \%$ (or roughly 2 standard deviations) of the international norm reflects acute undernutrition. Using this criterion, Malawi i and Madagascar probably had roughly the same degree of acute undernutrition and, moreover, a higher degree than most other African nations. For Malawii, some expected differ- 


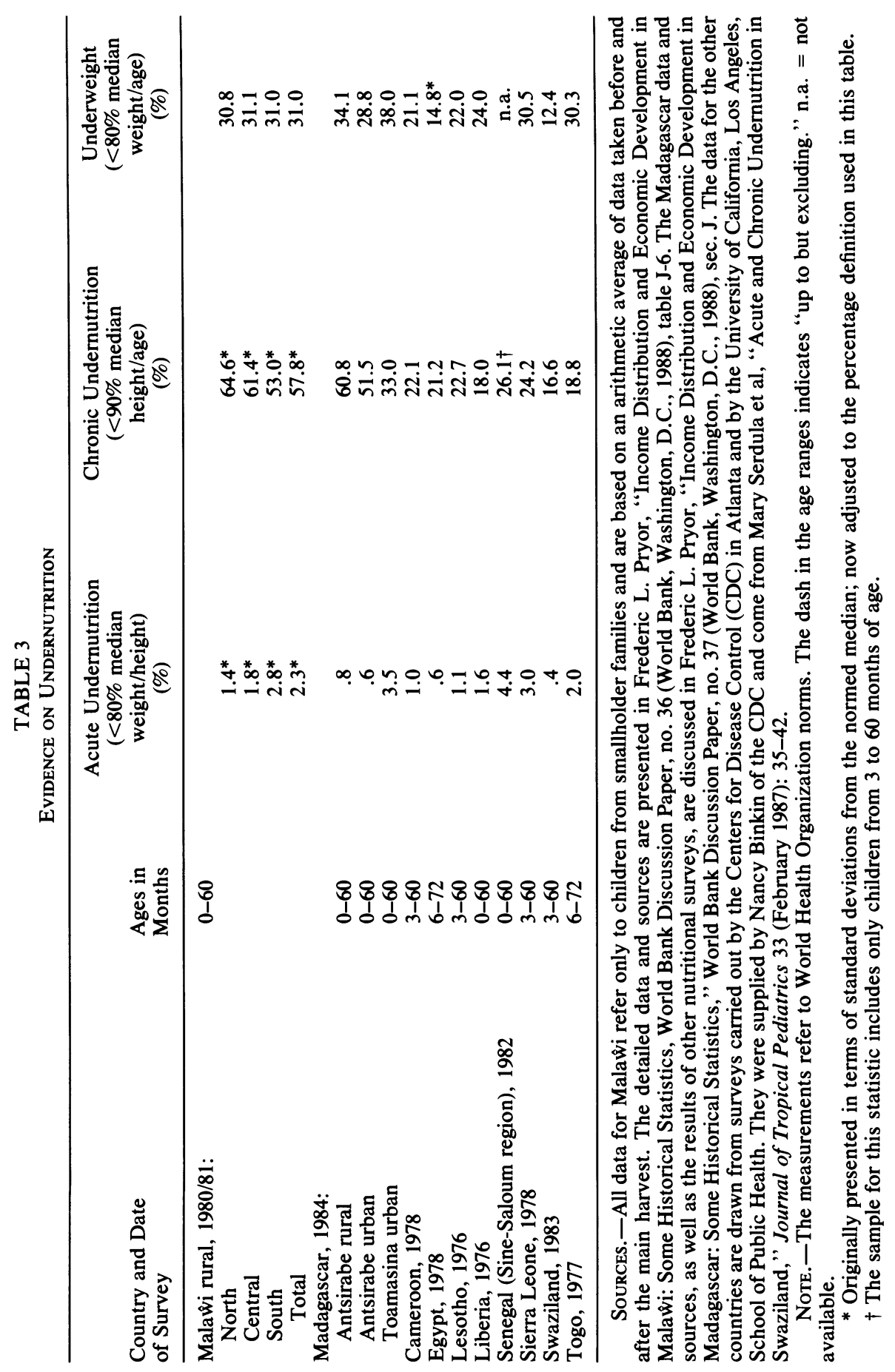


ences appear when comparisons are made before and after the harvest. Furthermore, the highest acute undernutrition occurred in the southern region where family incomes are lowest and land scarcity is greatest.

The height/age norm has some problems as a measure of chronic undernourishment, especially because of the controversy concerning the cutoff point to designate undernutrition. Although 90\% (about 2 standard deviations) is used in table 3 , some experts place the cutoff point at $85 \%$ or 3 standard deviations, which would reduce the count of chronically undernourished roughly by half.

By this measure both Malawi and Madagascar had a high degree of chronic undernutrition, about $50 \%-60 \%$ of their children. This appears much higher than in other African nations and, given the relatively low acute undernutrition, such results seem rather peculiar. To interpret these data, two conjectures can be offered: either the children in the two countries suffered from repeated spells of illness, which meant that they might not have been acutely undernourished at any single time but that the long run impact of such sickness led to a cumulative stunting, or the ages of the Malawiian and Malagasy children were considerably overestimated. Lacking detailed data, a definitive resolution of this interpretative problem cannot be given.

The weight/age norm is the most popular method of measuring chronic protein-calorie undernutrition. It is also, however, the most ambiguous of the three measurements for several reasons. It is quite sensitive to estimates of age; and among a population with considerable illiteracy, age estimates in months are often rather uncertain. Furthermore, different investigators define undernutrition at different levels-from $75 \%$ to $90 \%$ of the World Health Organization (WHO) norms. Moreover, the presence of edema may make weight misleadingly high. Finally, children with low weight for age do not necessarily have marasmus but may be short for their age so that their low weight is appropriate for their low height, a situation that seemed to be the case in Malawi i. ${ }^{23}$

These weight/age data suggest that about one-third of the children in Malaŵi and Madagascar were undernourished. These figures are somewhat higher than for the other African countries, but much lower than for some developing countries elsewhere. Weight/age data for other areas from other, less complete, studies (which are not shown in the table) suggest that undernutrition is somewhat greater in Madagascar than in Malawii. ${ }^{24}$

In sum, the anthropometric data suggest that the critical problem in both Malawi and Madagascar was chronic rather than acute undernutrition. Further, there appeared few important differences between the two countries: data for Antsirabe (a wealthy area) suggest lower undernutrition than in Malawii, while the data from Toamasina (a poorer area) suggest the reverse. 


\section{Poverty Trends}

Times series for an assessment of trends are considerably more problematic, and only the infant mortality data permit comparisons between the two countries. ${ }^{25}$

The decrease in infant mortality in Malawii, as noted above, does not provide unambiguous evidence about a decline in poverty. The increase in infant mortality in Madagascar strongly suggests an increase in absolute poverty, since the infant mortality rate is highly sensitive to changes in income of the very poorest. This conclusion is supported by scattered data showing that in the 1980s an increasingly higher percentage of children admitted to certain hospitals showed signs of undernutrition. ${ }^{26}$ Starvation also appears to have increased in recent years although little reliable information on the subject is available. For instance, the opposition leader, Monja Jaona, noted in a speech in October 1986 that about 47,000 people had recently died from hunger in three areas in the southern part of the island. The government officially denied the number but did accept the fact that some such deaths had occurred.

The increase of poverty in Madagascar was due in greatest measure to those governmental economic policies that led to a reduction in average income following the fall of the Tsiranana government. In particular, the shift in relative prices against the agricultural sector discouraged agricultural production for the market. The "invest to the hilt" program, the overvalued exchange rate, other foreign trade policies, and governmental expenditures directed toward the maintenance of large armed forces rather than for other purposes led to a general shortage of inputs.

\section{Growth and Income Distribution: Some Conclusions}

It was certainly not inevitable that economic growth be accompanied by widening income differentials in Malawi. The last decade of the colonial years in that country provided some evidence that, given the right set of incentives, production and incomes in the smallholder sector could grow rapidly. It was also not inevitable that Madagascar experience both an economic decline and an increase in income differentials. In both countries the major cause of overall increases in income inequality can be traced to a widening of income differentials among smallholders caused by a variety of policy failures, almost all of which were correctable.

Some general conclusions that have relevance for other nations can be drawn from these comparisons of Malawii and Madagascar.

1. In discussions about the relationship of economic growth and income distribution in developing countries, too much attention has focused on the urban sector. In poor agricultural countries such as Malawi and Madagascar, income changes within the rural sector or 
between the rural and urban sectors have been more important determinants of the inequality of income. Furthermore, the mechanism proposed by Simon Kuznets that linked economic growth, the transfer of workers from the rural sector to the urban sector, and the increasing inequality in the overall distribution of income does not appear very important in explaining what happened in these nations. ${ }^{27}$

2. Governmental emphasis on agricultural growth does not necessarily insure that rural incomes, especially of smallholders, will dramatically rise or that such incomes will become more equal. The Malawi experience shows that such agricultural growth can be focused primarily on the estate sector and the richest smallholders, so that income inequalities in the smallholder sector will widen. Unfortunately, the obvious fact that the agricultural sector is not homogeneous seems overlooked by many who make facile generalizations about development strategies and income distribution.

3. Government policies that have nothing to do with the distribution of income per se can have extremely important influences on income inequalities. In both countries administrative procedures concerning credit and the sale of agricultural inputs have acted to favor the richer farmers. In Malawi the two-tier agricultural pricing policies have widened income differentials. In Madagascar the nationalization of crop purchasing and sales to farmers had the same result; in addition, neglect of transportation maintenance led to a breakdown of rural markets, which acted to widen income differentials.

4. The tax system has an important role to play in the distribution of income. As shown in table 1, the incidence of direct and indirect taxes in Malawi was mildly progressive but no such incidence was observed in Madagascar. If, however, account is taken of the implicit taxes on the rural sector through low prices offered by monopsonistic crop purchasing agencies, the impact of the fiscal system in both nations was regressive since it placed a burden on the poorest segment of the population, the smallholders. This is true of many countries in many poor agricultural nations. In such cases an equilibrium exchange rate, which would raise the market prices for agriculture, would probably do more to narrow income inequalities than any other single set of measures. Unfortunately, politics in most developing nations are primarily urban matters since the rural areas are difficult to organize for political purposes. Such urban bias in the tax structure, while regrettable, is not surprising.

5. Commonly used overall measures of income inequality tell us little about the relative importance or behavior of poverty in an absolute sense. For instance, although Malawii had a greater income inequality than Madagascar, the various health indicators suggest that the two nations had roughly the same degree of poverty. Overall measures also show a greater increase in income inequality in Malawi than 
in Madagascar; as measured by infant mortality rates, however, poverty appeared to increase more in Madagascar.

6. Many direct measures to redistribute income are unlikely to achieve their desired ends. Given the fiscal constraints facing both governments, the extent to which redistribution of income can be carried out through the expenditure side of the government budget is highly limited.

The detailed study of income distribution trends in the poorest nations of the world is important in order to design policies, especially concerning agriculture, that can bring about both growth and equity. A beginning has been made by others, ${ }^{28}$ and in this study I have tried to investigate other aspects of the problem, especially with regard to policies that have hitherto received relatively little attention. Such a task, of course, is difficult, for it involves both piecing together relatively poor quality data and linking trends in income distribution with particular policies. Such linkages can only be determined by microstudies of the ways in which such policies have worked out in particular countries; and the major analytic problem is to separate the impact of different economic policies.

In addition, this type of case study evidence would probably not be of sufficient quality and quantity to carry out a sophisticated crosscountry or intracountry statistical analysis or to sort out unambiguously the major causal factors involved. Nevertheless, a sufficient amount of systematic case study materials linking policies and income distribution trends can be gathered to generate presumptive cases for or against certain types of governmental measures in particular situations, especially if such evidence buttresses existing theoretical evidence. Theoretical evidence alone is often disregarded by policymakers because it is difficult for them to gain a clear understanding of abstract relationships.

In sum, the lists of factors that influence income distribution presented in this and other studies provide the bones for a useful analytic skeleton. For such work to have an impact on policy, we need to investigate more closely a greater variety of these bones and, moreover, to provide them with more flesh.

\section{Notes}

* This research was financed by the World Bank for its Comparative Project on the Political Economy of Poverty, Equity, and Growth, which was directed by Deepak Lal, Hla Myint, and George Psacharopoulos. For comments on previous drafts of this article I thank Jonathan Kydd, Guy Pourcet, Zora Pryor, and Larry Westphal, as well as fellow participants of the research project. The World Bank does not endorse any of my evidence or conclusions, and I alone am responsible for any errors. Please note that for both countries I am focusing on the period from independence in the early or mid-1960s to the mid-1980s. The discussion is in the past tense, since both economies have 
experienced considerable structural changes since then. Also, note that one adjectival form of Madagascar is Malagasy.

1. All growth rates in this essay are calculated by fitting an exponential curve to time series. The raw data come from Frederic L. Pryor, "Income Distribution and Economic Development in Madagascar: Some Historical Statistics" (hereafter 'Madagascar HS'), World Bank Discussion Paper, no. 37 (World Bank, Washington, D.C., 1988), app. E, and "Income Distribution and Economic Development in Malawii: Some Historical Statistics"' (hereafter "Malaŵi HS'), World Bank Discussion Paper, no. 36 (World Bank, Washington, D.C., 1988), app. E. According to the recent calculations of Robert Summers and Alan Heston, "A New Set of International Comparisons of Real Product and Price Level Estimates for 130 Countries, 1950-1985," Review of Income and Wealth 34 (March 1988): 1-25, the per capita GDP's of Malawii and Madagascar in 1980 were, respectively, $\$ 417$ and \$589.

2. These ideas draw deeply upon the approach of Gary S. Fields, Poverty, Inequality, and Development (Cambridge: Cambridge University Press, 1975), who noted that "without exception the results emerge that variations within sectors or regions are much more important in accounting for inequality than variations between sectors"' (p. 115). This does not appear true in a static sense for either country; however, it does describe the trends of income for both.

3. "Madagascar HS,"' app. I, and "Malawii HS," app. I.

4. Estimate $B$ for Madagascar is considerably more comparable to the Malawi data than estimate A; unfortunately, estimate B could not be made for the later year.

5. For the smallholder sector in Malawi, the Gini coefficients of planted land per household were .369 and .381 in 1968/69 and 1984/85, respectively (per family member, these Gini coefficients were, respectively, .294 and .296). For the smallholder sector in Madagascar, the Gini coefficient of total land per household was .445 in 1962; and the Gini coefficient for planted land per household was .380 in 1984/85. These data come from Frederic L. Pryor, Malawi iand Madagascar (Oxford: Oxford University Press, 1990, in press), appendix, unrevised table A-2.

6. Although urbanization increased in both Malawi and Madagascar, the rates were considerably less than many other developing countries have experienced. In Malawi, between 1966 and 1977, the total population grew at an average annual rate of $2.9 \%$, while population in the urban areas increased somewhere between 4.7\% and 8.0\%. In Madagascar, between 1966 and 1985, the population grew at an average rate of $2.5 \%$, while population in the urban areas was increasing at a rate of $6.1 \%$. In both countries, the urban population increased somewhat faster in the smaller urban centers than in the large cities (where average incomes were relatively higher). The data come from "Madagascar HS," app. A, and "Malaŵi HS," app. A. The simulations mentioned in the text involve recalculating the inequality coefficients with different assumptions about the population in various groups.

7. Regional income data for both countries are presented in Pryor, Malâwi and Madagascar, appendix, unrevised table I-1.

8. This is argued in detail in ibid.

9. In the past, smallholders were often reluctant to form a cooperative to obtain credit and purchase fertilizer because all would be responsible for the debts of a single individual. The discussion of the proposed changes in the coming decade is found in Malawii, Office of the President and Cabinet, Statement of Development Policies, 1987-1996 (Zomba: Government Printer, 1988). Among other things, the plan argued that fertilizer should be sold in smaller 
sacks so that it could be purchased by smallholders with relatively small holdings.

10. I have argued this in greater detail in Malawi i and Madagascar.

11. The data mentioned in this and the following paragraph come from ibid., chap. 12.

12. This mechanism is spelled out more completely by Deepak Lal, "Stolper-Samuelson-Rybczynski in the Pacific: Real Wages and Exchange Rates in the Philippines, 1956-78," Journal of Development Economics 21 (April 1986): 181-204.

13. Katherine Sierra, "Malaŵi: Employment Aspects of Economic Development," World Bank Report 3453-MAI (World Bank, Washington, D.C., 1981).

14. Malaŵi, National Statistical Office, Malâ̂i Population Census, 1977: Analytical Report (Zomba: Government Printer, 1984), p. 167, reported that unemployment amounted to about $4.8 \%$ of the economically active in the urban sector, and $1.9 \%$ of the economically active in the rural sector. A smaller-scale survey, which is reported by Katherine Sierra, Malawi $i$ Employment Aspects of Economic Development, World Bank Report No. 3453-MAI (Washington, D.C., 1981), pp. 17-20 and was carried out in Blantyre in 1972, shows a similarly low unemployment rate: $3.7 \%$ of the labor force, mostly among poorly educated workers. Data to support other arguments in this paragraph come from "Malawi HS" (n. 1 above), table J-3. It is noteworthy that in the late 1960s, according to Robert A. Jones and Roger J. Robinson, "Income Distribution and Development: Rhodesia and Malawii Compared," Rhodesian Journal of Economics 10 (June 1976): 91-103, Southern Rhodesia had even greater inequalities of wages and salaries than did Malawii, even though in a relative sense it had a much greater pool of skilled labor on which to draw. Therefore, some of these urban income inequalities were due less to education than to nonmarket forces.

15. The data on wages and the labor force are very scattered and incomplete. The data used in this discussion come from "Madagascar HS" (n. 1 above), sec. $\mathrm{H}$.

16. An estimate of unemployment in Antananarivo is presented in United Nations International Children's Emergency Fund (UNICEF), Situation Analysis of the Child in Madagascar (Nairobi: UNICEF, 1984), p. 12, which is said to be low, since underemployment is not included. Unfortunately, no source is cited for their estimate. Unemployment data in Madagascar are quite fragmentary. Such data are not presented in the 1966 census, and the claim by Madagascar, Institut national de la statistique et de la recherche économique (INSRE), Recensement 1975, série études et analyse: Analyse de données socio-économiques, milieu urbain (Antananarivo: INSRE, n.d.), p. 17, of an urban unemployment of only 15,090 seems highly underestimated, since it is little higher than those registered as looking for work in that year.

17. Using data from tables I-4 and I-9 from "Malawi HS" and employing graphical interpolation methods, it appears that families in the fortieth percentile had an annual income of roughly MK 70.5 in 1968/69 (MK = Malaŵi Kwacha). In 1984/85, this income corresponded in real terms to an annual income of MK 333, which was roughly the income of a family in the sixtieth percentile. Using data from tables I-4 and I-8 from "Madagascar HS" (estimate A), it appears that in 1962 families in the fortieth percentile had an annual income of roughly FMG 47,400 (Malagasy Francs). In 1980 this income corresponded in real terms to an annual income of about FMG 146,400, which was roughly the income of a family in the forty-fifth percentile. The estimates for 
both countries are particularly sensitive to the assumptions made in calculating changes in average incomes of smallholders. Given the rough nature of the data, it is best to use caution in interpreting these quantitative results in a qualitative fashion.

18. For instance, I found no evidence in Malawii of groups of people living on the food at the garbage dumps, a phenomenon described in vivid detail for Madagascar by Martine Camacho, Les poubelles de la survie: La décharge municipale de Tananarive (Paris: l'Harmattan, 1986). The quantitative extent of the poverty problem is difficult to determine in either country, since neither the Malawii nor the Malagasy governments have published any extensive studies on the subject. Malawi has no "official" poverty limit and in my interview with him, President Banda quickly dismissed the suggestion that poverty in his nation had increased (Malawii, April 22, 1987). The Malagasy government is more conscious of the problem, particularly for the urban areas, and has tried to gain some idea of its magnitude. Unfortunately, the government does not appear to have followed a consistent approach and calculations of the level of "absolute poverty" for a family have varied over the years from about FMG 24,000 to FMG 54,000 per month (in constant 1985 FMG). More specifically, for a family of two persons this limit (current prices) was FMG 13,000 and FMG 28,000 per month in 1981 and 1985, respectively. (Madagascar, Ministère des travaux publics, Schema directeur du grand Antananarivo: Projet de rapport final de synthèse, Project MAG 82/011 [Antananarivo: Ministère des travaux publics, 1985]). A different monthly poverty line declared the level to be FMG 9,317 in 1971; FMG 13,658 in 1975; and FMG 15,000 in 1977. (Madagascar, Direction générale au plan, Revenues des ménages urbains et satisfaction des besoins fondamentaux á Madagascar, Études techniques du plan, no. 22 [Antananarivo: Direction générale au plan, 1979]). An interesting qualitative discussion of poverty in Madagascar is by Jean Claude Rouveyran, La logique des agricultures de transition (Paris: Maisonneuve \& Larose, 1972).

19. These data on infant mortality come from "Malawi HS," table J-5. Malawî, Statistical Organization, Malaŵi Family Formation Survey, 1984 (Zomba: Government Printer, 1987), places the infant mortality in 1983 at 154 per thousand.

20. Various estimates of infant mortality, including my own, are discussed in much more detail in "Madagascar HS," sec. J. Some data on rising mortality, fetal, and neonatal mortality from 1978 through 1984 are presented by World Bank, "Madagascar: Population and Health Sector Review," Report no. 6446-MAG (World Bank, Washington, D.C., 1986), app. 2. Some annual data, which refer to the number of malnourished children, can be found in Célestine Rabemiafala, Contribution à évaluation de l'état nutritionnel des enfants malagasy de moins de 6 ans à travers le complexe materno-infantile de Tsaralalana (Ville d'Antananarivo) (Thèse, Doctorat de medicine, Université de Madagascar, Antananarivo, 1984), p. 445.

21. The Malawî data come from Malawii, Minister of Health, World Health Organization (WHO), and UNICEF, Report of the Joint Program Review of Maternal and Child Health (Lilongwe: Minister of Health, WHO, and UNICEF, 1986), p. 46. The Madagascar data come from WHO, Study of the Epidemiological Aspects of Breast-Feeding in Madagascar, Project 62/ MAFA/WHO, Preliminary Report (Antananarivo: WHO, n.d.). The statistics reported in these two sources are considerably higher than those reported by UNICEF, The State of the World's Children 1986 (London: Oxford University Press, 1986)-12\% for Malaŵi, $10 \%$ for Madagascar.

22. The discussion of measurements of undernutrition in this section is based on Charlotte G. Neumann, "Reference Data," in Derrick B. Jelliffe and 
E. F. Patrice Jelliffe, eds., Human Nutrition: A Comprehensive Treatise (New York: Plenum, 1979), pp. 299-327; and Derrick B. Jelliffe, Assessment of Nutritional Status of the Community, Monograph vol. 53 (Geneva: WHO, 1966); and conversations with Nancy Binkin (Swarthmore, Pa., 1988), nutrition specialist of the Centers for Disease Control in Atlanta, Georgia. By restricting the sample to children under five, the influence of racial factors is minimized; most well-nourished children in all countries have the same age specific height-weight patterns until their sixtieth month, a hypothesis explicitly confirmed in a special study of Malawi (unfortunately no such study is available for Madagascar). More specifically, Beatrice Mary Chimwaza, "Food and Nutrition in Malawii" (Ph.D. thesis, Faculty of Science, University of London, 1982) made anthropometric measurements on children in a rural area (Dowa) and in a middle-class urban area (Lilongwe) and concluded from the latter sample: "For height, weight, and arm circumference, the results obtained in the present study seem to indicate that the international standards used are appropriate for assessing growth of the Malawian children" (p. 229). To my knowledge no similar study has been made in Madagascar, which is racially quite different from Malawi. However, my conversation with specialists in Madagascar on this question did not reveal any indication that international norms were inappropriate.

23. A special problem arises in the estimates for Malawi in that they do not use an international standard but, rather, a norm based on the Malawi median in order to take racial differences into account; however, if less than $50 \%$ (which seems to be the case) of the nation's children are undernourished, this is an appropriate procedure.

24. These data are reported in "Malawi HS" (n. 1 above), table J-3.

25. For Malawi, certain data on the weight/age ratios of children are available from 1970 through 1984 and are cited by Louis A. H. Msukwa, "Agricultural Development and Undernutrition: The Case of Malawi i”' (paper presented at the second annual conference on Food Security Research in Southern Africa, Harare, November 1986). Although interesting, such data are not sufficiently comparable for trends to be discerned. The same may be said for the nutrition data presented in "Malawi HS," table J-3.

26. Such data were shown to me by officials of the Catholic Relief Service in Antananarivo. Certain Malagasy officials who have opposed the structural adjustment program have also argued that an increase in general poverty has occurred because the average household size increased from 1975 to 1985 , thus indicating a doubling up of families. However, the available data suggest that the average household size was about the same in both 1966 and 1985; Madagascar, INSRE, Recensement 1975, Série études et analyse: Les ménages (Antananarivo: INSRE, n.d.) p. 7, suggests that the ostensible fall in average household size in $\mathbf{1 9 7 5}$ was a statistical artifact, due to the fact that the question of household size was posed somewhat differently than in 1966. Therefore, the alleged rise in household size between 1975 and 1985 is probably a statistical artifact as well.

27. Simon Kuznets, "Economic Growth and Income Inequality," American Economic Review 45 (March 1955): 1-28.

28. For instance, the study by E. Wayne Nafziger, Inequality in Africa: Political Elites, Proletariat, Peasants and the Poor (Cambridge: Cambridge University Press, 1988). 